\title{
Poetic Updates In Uzbek Literature (On The Example Of Prose Masterpiece)
}

\author{
Khamrakulova Khurshida Kuvvatovna, \\ Doctor of philological sciences, University of Uzbek language and literature, Named after Alisher Navoi \\ Xxurshida@mail.ru
}

\begin{abstract}
As a result of the renewal of national thinking, the events of life and the principles of the approach to the human person in Uzbek prose also changed and began to take on new forms. In a number of prose works, we find images of courageous people who have not lost their identity and faith over the years. At the same time, we are confronted with those who, under ideological pressure, have turned to "modernity", apostatized, deceived and become servants of a deceptive and violent ideology. We see that the hypocrisy inherent in such images is portrayed in all its horrors. It can be seen that in Uzbek prose works the attempt to reflect the unique nature, unique world, past and feelings of the nation has become a certain aesthetic principle, and such positive research serves as a basis for significant growth in prose. The works we have analyzed not only renew epic thinking in one way or another, but also serve as a basis for the emergence of new trends, currents and directions in literary life. As a result, it influences the development of socio-spiritual and artistic aesthetic thinking.
\end{abstract}

Keywords:

proze work, masterpiece, modernity, literature, spirit of the protagonist, humanity, tragedy.

Article Received: 18 October 2020, Revised: 3 November 2020, Accepted: 24 December 2020

Interest in purely human and natural problems related to human life, nature, psyche is a characteristic feature of our national literature today. Although the events associated with death in our view evoke unpleasant impressions in the human heart, for those who understand the purpose of life, death is not an absolute disappearance, but a connection to the eternal world. There is a birth, there is an end. But there is also wisdom in reaching the end of life with good deeds. The works of art that shed light on the problem of life and death show that in our literature today, the principle of an unexpected, new approach to the old problem is becoming a priority. In the literature of the independence period, the artistic interpretation of the philosophy of life and death is expressed in all genres of prose. One of the most important aspects of the prose of independence is that there has been a literary mutation not only in the image but also in the expression of the psyche. Mutation is explained by genetic changes in medicine. But the works of art that underlie the various interpretations that tore through the shell of social realism that had prevailed for so many years created a literary mutation. This event in a positive sense allowed the reader to look at reality from different angles. Now the reader can easily enter the inner world of the character, inspect every corner of it and understand others and the world between life and death. While N.Eshanqul's works focus on the intricacies of the character's psyche, In X.Dostmuhammad's story "The Road to Silence" we encounter a divine interpretation of the problem. In the works of Z.Kurolboy's daughter, problems related to human natural inclinations are described. In the works of N. Eshonqul, the experiences of the protagonist, especially the female characters, are expressively and delicately expressed. This is also typical of the work of L.Borikhan. The writer is not stingy with words. The darkness of the image does not spare the word for the bulging appearance of the female psychodynamics. But behind every word, there is an artistic bubble paint of its own style. The reason this paint has a certain aesthetic print is a 
tragic column in the psyche landscape line. The same tragedy adds color to the works. The subtle mysteries of the human heart arise in tragic situations, not in the realms of everyday life. It is no coincidence that the fact that our writers emphasize a certain situation in revealing the experiences of the soul, as well as the fact that the best works are sealed for eternity, is associated with tragedy. Because the true image of man is determined by mental anguish. Suffering affects the heart of the reader. Naturally, as a result of these effects, the heart becomes kinder. The call to goodness is the basis of fiction. Because of this, the human mind is in tune with the literature.

Describing the relationship of the couple, which has become an obligation, N. Eshanqul focuses on the natural factors of man. This was reflected in his story The Unopened Door. The basic necessary condition of the family is also measured by the proportionality of physiological relationships. It is well known that before any value can acquire sociality, it must be saturated with naturalness. Values in the family are also formed on the basis of natural harmony. You need to have a decent family to organize the community. Naturalization is necessary for socialization. The writer therefore focuses on the couple's relationship, which is considered a necessary condition for the family without leaving any objections. The ending of the work reassures the reader, no matter how sad. This is an aesthetic flavor that the writer can present to the reader. The end of the story ends with the bride drinking poison. At this point, the writer focuses on the bride's inner world, not her outer state. Such a situation is natural for anomalous suicide. Because the bride is forgotten, her condition is ill-wicked. Her logical conclusion was death, and in this regard the writer acted in the spirit of the protagonist.

We have focused on cases of poisoning and death of several characters in relation to the topic. In contrast, Nazar Eshanqul describes the hero's voluntary choice of death and his experiences in this situation. These moments were more important than a woman's lifelong life. In many cases, it is difficult for the soul to separate from the body, but for a person who is fed up with life, the image of the soul enjoying separation from the body was the writer's development.

The author describes not the torture of the soul, but the flight of the soul into another world: he was taken aback. ${ }^{1}$ A peculiar description of the separation of the soul from the body is expressed in the story "The Death of Ivan Ilyich."In Uzbek prose, such an image is reflected in the prose of the years of independence, in particular, in the works of N.Eshonqul, H.Dostmuhammad, Z.Kurolboy's daughter.

The alienation of man requires his existence. And death confirms existence. This is also a feature of world literature. R.Thokur's story "Dead or Alive" is an example of this. The tragedy that befell the protagonist Kadomini ends with his death proving his life. Regarding the fact that the theme of death is often mentioned in the author's work, Chulpon writes in his article "Who is Tagore?" That is why death is so common in his works. In 1885 his wife, son, and daughter died; in 1905 the youngest son and father died. In 1918 another daughter died. ${ }^{2}$ "In order to understand tragedy, a person's worldview and spirituality must be at the level of tragedy. ${ }^{3}$ "In Thokur's work, the theme of death is largely social, and by covering the subject, the problems that are troubling the nation's destiny are solved. If attention is paid, the question of the role of death in human existence remains central to the analyzed works. Existentialists who deal with the problem of human existence say that the essence of life is not revealed in human existence, explaining its cause by the alienation of man. So far, this alienation has gone through three stages. The condition of the characters to be analyzed in

\footnotetext{
${ }^{1}$ Eshonqul N. An unopened door. You can't catch the wind.

- Tashkent: National Library of Uzbekistan, 2005, p. 72.

${ }^{2}$ Chulpon. What is the literature? - Tashkent: Chulpon.1993, p. 63.

${ }^{3}$ Yuldashev K. A firing word - Tashkent: New Century Generation, 2006, p. 118.
} 
our chapter corresponds to the second and third stages of alienation. That is, the rise of science and technology, the division of humanity, which was once one, into nations, peoples, and states, and as a result, the separation of man from the bonds of brotherhood both in nature and in human society; that man is alienated from his inner world. The reason for this is that man loses his inner nature and adapts only to the external nature. It has also been stated in foreign literature that a person's isolation from society causes him to choose death voluntarily. For example, the Japanese writer Shimada Masahiko's "Diary of a mummy"4 tells the story of a starving man who forced himself to die and traveled to another world after sixty-two days of hardship. By reading this kind of work, in which the pre-mortem states are directly observed by itself, recorded in every book of change, we feel that a person can withstand any test. By the way, suicide is not a tragedy in Japan. They are suicidal with the belief that seppuku (suicide) will erase all the humiliations in this world, which means that a meaningless life can be changed for the better through death. Often, helpless people choose this method of death with the desire to be born into a good family in the next life. In Japanese suicide bombers, suicide stems from a desire to be heroic. We can learn about this from Said Ahmad's story "Sun Mother". When the Japanese samurai are in danger of being captured, they commit suicide, and when the country is in danger, the kamikazes (kamikaze - "bullet man") fly to the enemy's stronghold in a single-man plane with a terrible bomb. The plane is refueled just enough to fly. If the pilot is cowardly and wants to go back, there is no fuel to go back. "Kamikaze must hit the enemy's arsenal and blow himself up." 5 Thus, suicide in Japan also occurs for specific reasons.

Masahiko tries to prove the freedom of the soul by finding voluntary death, concluding that

\footnotetext{
${ }^{4}$ Masahiko Sh. A diary of mummy (translated from English by A. Obidov).ziyouz.com

${ }^{5}$ Ahmad S. The sun is shining. The cock is crazy. -

Tashkent: Uzbekistan, 2001, p. 79.
}

the protagonist "this world is not worth living for me." "What was lying on the straw was a dead body. The mummy, wrapped to hide from the cold, was covered in light dust, and the body was as hard as a razor. The exposed parts of his cracked skin were like dark-skinned leather boots, and his eyes were as hard and bare as if they had sunk into his chin. A thick beard hung from his chin, a thin lump on his lower lip had hardened and his abdomen was completely penetrated. The body was protected from decay and was well dried. Apparently, while he was still alive, he gradually lost weight to make it easier for his body to harden like a mummy. " The observer's attention is drawn to the diary under the corpse's feet. The cause of death was covered in detail in the diary. The author notes that no one was looking for the owner of the body in one place, not even the police court on the list of the missing. The protagonist is forgotten in this position, and the reason why he is looking for a reason to die becomes clear. An analysis of the characters belonging to the hero who committed suicide through starvation shows that he has a sign of anomalous suicide. The first days of starvation are relatively easy. The protagonist tends to drink water and listen to music. On the eleventh day of the famine, he hears on the radio that three close brothers who are in high school in Tokyo have drowned themselves. There is some truth in this information. Because suicide among Japanese youth, as mentioned above, is mainly related to the desire to be born into a good family in the next life. Again, psychologists have found that juveniles also commit suicide to make their parents regret it.

Masahiko notes that hunger has gradually taken its toll, his body has become heavier, his urine has turned bloody, and his body is not obeying him. If in the first days the desire to eat bread increased in his dream, then he will no longer have the desire. The stomach starts to ache. At one point, the protagonist thinks, "Although I'm not religious, I have a lot of respect for many gods in the world, because no god can have mercy 
on me somewhere." On the thirty-eighth day of the protagonist, "I realize that the soul requires a great deal of energy to leave the body. The spirit is eating my flesh to gather strength", -he wrote. He thinks that if there is no life after a sudden death, there is no need to suffer, but he does not want to go back, because the present suffering was more meaningful than going back. Thus, on the sixty-second day of the famine, he ends his life by saying, "Peace will be upon you". The story tells the reader that the meaningless life of a hopeless man has made sense through the feeling of death.

The life of the protagonist of the work indicates that he was denied not only by society but also by his own nature. Indeed, the question of human existence could have been a problem of society, which was written in time by existentialists. Analysis and interpretations have shown that the extent to which a person lives, as well as the circumstances leading up to death are also linked to his actions. But the Merciful Creator does not disappoint the hopeful.

The scene of forced preparation for death is also found in Abdukayum Yuldashev's story "Trace in the Heart". In the words of the protagonist Erjigit, "I have to die. There is no other way". ${ }^{6}$ Throughout the story, Erjigit's chronic illness, his attempts to survive, and the fact that he eventually causes a family to fall apart, torment him mentally and make him want to die. If the view that life is not worth living in the hero of Sh.

The story "The Road to the Silence" (H. Dostmuhammad), which reflects the fascination of the spiritual world, tells about the unknown aspects of human nature. The play, based on the story of Italian writer Dino Butstsati's "Seven Floors", focuses on the Islamic approach and nationalism. Dino Butstsati emphasizes the issue of society and the individual, revealing the deteriorating relationship between the individual and society through the occasional transfer of the

\footnotetext{
${ }^{6}$ A. Yuldashev. Trace in the heart. Goodbye beauty. -

Tashkent: Uzbekistan, 2011, p.
}

protagonist to the floors of the building and the tragic state of the dying character.Maybe this life exists only in this world, death is a reflection of the idea that it is the end. That's why Butstsati's protagonists have a strong desire to stay in the existing world. Through the fate of the protagonists, the writer reveals the character of different categories of people, and most importantly, the same attitude of each to the dead and dying.

The main goal is not to bring the buttsati hero Giuseppe Corte to the brink of death, despite his unwillingness to resist. The writer raises the low relationship between society and the individual to the level of a problem and presents death as an artistic solution. In the interpretation of $\mathrm{H}$. Dostmuhammad, the spiritual aspects of the person come to the fore. As the writer mediates death to know the world understood and unknowingly, he thus reveals the essence of life. The protagonist breaks the boundaries of life and death through his actions. As a result, the purely Islamic interpretation death is a bond, not an end, before our eyes finds its beautiful expression. Dino Corte in H. Dostmuhammad's Nazira-story is radically different from Giuseppe Cortes of Butstsati. While Giuseppe Corte rebels against the cruel order of society, Dino Corte rebels against death. He does not want to admit death. In contrast, Zahid Yakin is ready for death and does not consider it a tragedy. The beliefs of the owners of the two different environments were also summed up in their attitudes toward death. Although the story of the Uzbek writer is based on the work of Dino Butstsati, not to mention the similarity of the names of the floors and heroes, they are completely different works in terms of content and purpose. In this way, both writers analyze the fate of the protagonists using symbols placed on the seven floors of the hospital, effectively using the contrast method to create scenes that encourage the reader to observe. Man's desire to know death and the sins associated with it, on the one hand, is also related to his concern for his own destiny. So that the 
human destiny always stays mysterious. Death is the veil of that mystery. When the curtain rises, man becomes aware of his destiny. Until then, that curtain is trying to understand the essence. No matter what system a person represents, no matter what idea he carries, he is inseparable from his destination. And this address is of course achieved through death. "None of you will leave this world until he knows where his destination is and sees whether his place is heaven or hell," 7 the Hadith says. This means that man determines his own address. Death is a divine event that recognizes the Creator to the creature, meaning to him the Creator. It is enough to remember only the fate of Moses and Pharaoh. Behind death is the true reward of the eternal world. The foundation for reward is laid in this world. That is why death, which is the writing of destiny, has always been the focus of humanity. He conquers every sphere of existence with his power. This is not in vain, for the essence is reflected in the path that leads to death. The essence is the truth. And the way of truth, as Chulpon said, is really a pasture. Fiction serves as a beacon in terms of conveying this essence to man. Death is also a factor that glorifies great tragic works. Death not only defines the original image of the protagonist, but also explores society, humanity, from the bottom up. The story focuses on an interesting aspect of human nature: man waits for death for a lifetime, but does not want to be met at the same time. Finally, Giuseppe reaches the first floor, which he has been waiting for but does not want to. The fall of the window shutters indicates that the moment of death has arrived. As the writer wanders the protagonist between floors, it reflects the inferior relationship between the individual and society. The writer also looks for the cause of the hero's death in this relationship.

Another story by Dino Butstsati, Why the Dead Don't Resurrect, also reflects death, the soul, and society's attitude toward it through the writer's

\footnotetext{
${ }^{7}$ Ghazzali Abu Hamid. A book to remember death -

Tashkent: Movarounnahr, 2004, p.49.
}

eyes. The writer makes a bitter joke about the deterioration of human relations by bringing the late violinist Appasher back to life one night. Friends who are ready for any situation to chase him out of the door to see his friend's house again last night. The writer introduces the deceased protagonist to different categories of people in society. See, each of them treats the deceased the same. The author points to the weakness of humanity, the fact that mankind can never be ready for the equestrian position of death, that death and the events associated with it are unimaginable, in a word, they perceive death as a horror. That is why the author allows the protagonist of the story "Seven Floors" Corte to revolt against society and thus death what matters to Dino Butstsati is not what death is, but how the protagonist reacts to death. The issue of man and his attitude to death finds a special shape in the story "The Road to Silence." The story traces the rebellious, Islamic-spiritual interpretation of death in relation to Dino Corte, Zahid Yakin.

The deeds of Dino Korte and Zahid Yakin are summarized between the floors. The author does not elaborate on the ascension of Zahid Yakin to the upper floors one by one, from the fourth floor to the sixth floor. In fact, Zahid Yakin's life ends on the sixth floor. On the seventh floor is a priestly landscape. The names of the nurses attached to Zahid Yakin are also symbolic.

Mujahideen means "to act" in Arabic, "to do one's best", and Mushahi means "to witness something", "to look at something". Mujahidism, observation, passion, is a phenomenon related to the soul. The writer also refers to symbols because he has made the image of the human psyche a preissue.

At each step of the stairs, the life of Zahid Yakin is summarized. The encounter of the Mujahideen in the ascending phase, using all his strength, transforms the protagonist himself into a mujahideen. The writer focuses on the radio in each room. It is mentioned that this detail is often needed by the protagonist downstairs. But he 
won't need the hero anymore on the sixth floor. Because "a very quiet and attractive sound of music began to fall on his ears". Finally, the seventh floor in the author's interpretation was not related to the hospital. It was a floor spoken by the language of the characters, reserved only for angels. Writer Zahid Yakin's depiction of instantaneous moments in the spirit world is based to some extent on scientific truth.

The English scientist Dr. Raymond Modi's "Life after Death" gives a clear idea of the situation behind death. As a result of studying many facts, the scientist finds the following:

" 1 . The spirit can hear what is happening.

2. Feels peace and quiet.

3. Noise is heard. This noise can be unpleasant or as pleasant as music.

4. Once the soul is separated from the body, it can leave the tunnel.

5. Can observe itself outside the body.

6. He can see a transparent being or a bright light. ${ }^{8}$

It can be said that the posthumous condition of Zahid's loved one is not invented by the writer, but a reflection of a life event in art.

Commenting on the story "Road to the Silence", K. Yuldashev said that the dark view of the lowest floor to Corte, and in "The Road to the Silence" Zahid Yakin seemed to be covered with white light, are due to the uniqueness of the two faiths. That is, for Corte, life with this world is over. Zahid Yakin hopes for a bright and eternal life to begin now. In other words, death destroys the representative of the West, death raises the people of the East, brings them closer to the goal $^{9 \text { "' }}$,-he writes, and in a sense draws attention to the diversity of their beliefs. In fiction, there are also cases where the interpretation of the death of the protagonist is particularly lightly humorous. This tradition, which began with the work of A. Qahhor, culminates in the story "Sagana" by Said Ahmad. No matter how funny the story may be, it

\footnotetext{
${ }^{8}$ Moody R. Life after death - Tashkent: Labor, 1992, p. 118

${ }^{9}$ Yuldashev Q. Firing word. p.111
}

is important to confirm the infinity of the fanciful world with laughter, which is the basis for thinking. "It would be right for him to be wrapped in a shroud and lying motionless in a coffin," he said. The coffin is in the corridor, the shroud is on the shoulders of the mourner. But the story begins with the corpse shaking hands with passers-by in the courtyard, handing out trays from the window, and saying to those who ask, "What can I do if I'm a slave?" After that, the protagonist is openly treated. This relationship is supplemented in turn by the author's commentary. Although Said Ahmad's story is rich in humor, it reveals the flaws of human nature, as evidenced by the fact that a person's self-immolation in the throes of a lifetime becomes insignificant in the face of death.

It is impossible to catch the wind" is one of the most successful stories of N.Eshankul. It contains plates about the psyche of a single hero. The fate of the protagonist Bayna granny evokes a good mood in the heart of the reader. Behind his fierce gaze lurked the years of longing, the anguish. The author shows in the example of Bayna granny that the human psyche can change unexpectedly. Typically, the transition from one quality change to another quality phase takes a long time. So it is with human behavior. But as we get to know Grandma's fate, we encounter a completely different phenomenon. The change that results from a severe mental shock is more rapid than the change that development has gifted to humanity over the years. Man's experience over the years leaves a mark on his character. But there are also factors that suddenly turn human life into something else, creating a special scene in the eyes of people, which the author emphasizes in the example of death. It is understood that the oppression left in granny's heart was not due to people or her attitude towards them, but to death seems that death is not only a physical end, but also a reaction to death is not always the same. Bayna granny appeared in the form of an image that took on an aesthetic burden due to the death of her husband and son. He hid his hatred in his eyes for years. Even if he hates his whole body, he 
will not be as dangerous as a man who keeps silent. Bayna granny did not reply Zamon's these sentences: "If your husband was not here, he would have died somewhere else. Don't worry, if you die, my dogs won't bury you". Finally, the work concludes by saying that the years of revenge have not gone away: only the bone itself was left, and it was dark, and on the verge of turning to dust, ten human fingers were found wrapped in a torn piece of cloth ... ${ }^{10}$

N.Eshonqul's story "People of War" is close to the novel "People in the heat" by L.Burikhan. The story is not just a human tragedy, but a series of tragedies. National values, simplicity and sincerity in the nature of the people are also ingrained in the shell of universal tragedy. At the heart of the tragedy is war. Because of this, people become ruthless in the cycle of destiny. The struggle for immortality, the sacrifice of honor for not seeing the stain of a child, the murder for the honor of masculinity, is heavier, more tragic than the bloodshed in a war that is unclean. The return of the protagonist Normat from the war was a great joy, but a great tragedy awaited her - death and chaos. Anzirat's helplessness in the face of his cruel fate, the uncertain fate of unhappy children, the triumph of honor over compassion, the tragedy of Normat all this was a bitter part of the fate of the people after the war.

Human nature persists in spite of any pressure. So, there is also the issue of human existence in this place, so that he can survive the screams of time. Existence manifests itself in borderline situations, not all the time. In borderline situations, the original image of the person is visible. The origin of man is determined by his nature. Man, on the other hand, by nature acquires an appearance. Even war cannot interfere with the hero's natural desires. This situation is fully expressed through the image of Anzirat.The saddest parts of the work are also associated with

\footnotetext{
${ }^{10}$ Eshonqul N. You can't catch the wind. -Tashkent: National Library of Uzbekistan, 2005, p.13.
}

this image. The scourge of war is famine, and the tragic fate of her children, who are on the verge of death, outweighs her honor. "He couldn't rest all day, and he couldn't stand the girl in the crib and Holmat's shrinking body, the horrible, frantic step of starvation ${ }^{11 "}$. The step taken in such a situation read its verdict on his bitter fate. The forced step gradually gave way to voluntary desires. Even if the writer throws his protagonist into the clutches of life, he does not forget to show her femininity at every moment, as a person who cannot live apart from natural feelings. His whole body was on fire, his blood was flowing from his veins, his limbs were tense, his body was longing ... he felt a longing for something. This longing made him some days insanely nervous, raging, gnawing right at his heart, his whole body. Towards the end of that year, he began to become impatient with many things. The biggest intolerance happened later ${ }^{12} "$. The desire for unconditional help was greater than any tragedy expected. Later, both Anzirat and Mirzaqul fell victim to this desire. The pain between compulsion and inclination, honor and shame, takes on a peculiar spiritual landscape in the writer's pen. The thickening of the image confuses the character's state, confusing him in the middle. But the crowd is always crowded. There is no one who wants to understand, no one who can be an ointment to him. As a result, he becomes alienated from everyone. While justifying the protagonist's alienation from the crowd in the play, the writer pays special attention to the fact that man cannot exist outside of society and to the psychology of the masses. The crowd is unable to accept an event that is separate from it. The Anzirat tragedy was also caused by its deviation from the values formed over the centuries. However, the nation is behind the values. But the writer tended to portray the protagonist's experiences as a person, not his place in the nation's destiny, and he succeeded. A

\footnotetext{
${ }^{11}$ Eshonqul N. People of war. You can't catch the wind. Tashkent: National Library of Uzbekistan, 2005, 137 p

12 Eshonqul N. People of War, 138 p.
} 
person's place in society is not determined only by social relations or emotional relationship, the normalization of both situations stabilizes this place. Nevertheless, we cannot ignore the fact that man commits sin knowingly and consciously, and that the slave agrees with it, and that he is therefore a sinner. Anzirat is a victim of the situation. The saddest parts of the work are the plates in which the image of Anzirat is involved. Her fate is a hundred times sadder than that of other female characters of the writer, in particular, the protagonist of the story "The Unopened Door". "He did it to save the lives of my children, otherwise they would have died. But there was someone else here. The other person, another body, longed for Mirzaqul to caress him every day, to tickle his neck with his unshaven beard, to caress his hair with his hands, which he had not seen for three years $13 \%$. N. Eshankul's works "Unopened Door" and "People of War" focus on the issue of suicide. The fate of Normat in the story revealed selfish suicide.We have seen in the example of Saidi, the protagonist of the novel "Sarob", that as a result of severe mental trauma, a person stops thinking and becomes wrapped in his own shell. Saidi, seeing his sister's pain, and in this case his desire to live, wants to take all his pain from his sister and strangle her. In him, hatred grows so strong that he finds the strength to destroy an entire train. Normat Mirzaqul's squealing and squealing in a fit of rage evoke wild joy in him. The author likens Normat's situation to that of his "savage ancestors millions of years ago, who tore his opponent to pieces and are ready to tear him to pieces again." His laughter is also like the roar of a savage beast. While the writer shows his protagonist going out of balance on the border of life and death, he also rationally justifies his suicide. After all, suicide is not the result of a normal life. While highlighting the bitter fate of Normat, the author raises the issue of human tragedy, hunger and humiliation after the war, the healing of human endurance in trials, and the issue

\footnotetext{
${ }^{13}$ Eshonqul N. People of War, 144 p.
}

of honor and dignity. The vital, sincere output of the story is that the writer does not react to any of the characters, but describes them as they are. Characters are characterized by good and bad aspects, qualities and shortcomings, weaknesses and strengths. That is why they take on the image of Man and captivate the reader.

In the image of Normat in the interpretation of $\mathrm{N}$. Eshonqul there is a characteristic of the nation, tolerance, arrogance. He thought of everyone as his own, so he spread his wife's bedtime to his disability, embarrassed in front of her. But the reality is that suffering in the midst of honor and dignity defines his image. $\mathrm{He}$ cannot find the strength in himself to forgive his wife.

War doesn't mean we both want to lie like that. War - we don't want to earn a living with honest forehead skin, double driving, planting crops. He always wants to deprive us of these things. War is like a moving stone under your feet, whether you lift it or not, you will die ${ }^{14}$ ",-said Normat himself. Anzirat's betrayal ruined Normat's life. Until then, he will endure both the horrors of war and suffering. In order to return home alive, he feels the need to survive in order to reach Anzirat.To be one of the first to go to war, to show heroism, to be able to survive, to return as a hero even if he survived, was only to show that Anzirat deserved more. In the case of the writer Normat becoming the killer of Mirzaqul and Anzirat, the departure of the human psyche from a certain pattern leads to a disturbance of balance, in which a wild sensation is aroused. There is a sign in the climb of the norm that man is unconsciously striving from the organic world to the inorganic world.In general, it is natural for human beings to become like this from time to time. It manifests itself at different stages of human life. A person who lives a normal life is different from a person who is depressed. In the story, death is interpreted not only as a physical end, but as a protection of human dignity. Although war has brought disaster

\footnotetext{
${ }^{14}$ Eshonqul N. People of War. $154 \mathrm{p}$.
} 
to people, life goes on in its own way. The play gives the symbolic qualities of the seasons. The story begins in winter and ends in spring, signaling the beginning of a new life and the survival of the nation.

The story "People of War" describes the fate of people after the war, while the story "Crying over the river" by K.Norqobil describes the events of the Afghan war and the experiences of the protagonist Kochkor, who is dying every minute. The Afghan war was a shameful event. It doesn't matter who or why you fought there for, it was a great achievement to return home alive after serving in the military. The writer, with a critical eye, portrayed the scourge of war, the situations on the battlefield, character of the people through a variety of characters. There is a common denominator in works devoted to the depiction of war. It is the loss of a sense of fear in the face of death. This can be seen in Oybek's novels "The Sun Does Not Darken", Shuhrat's novels "Shinelli Years", and finally in the story "Crying behind the River". Although the works were written in different years, there is a ambiguity in the hero's attitude to death on the battlefield. The war and its complications, the events that took place in the mind of the hero after the battle are a separate issue. But in the confrontation with death, there is an objective reality in the depiction of the character's experiences at that moment. War does not allow us to think about death. The intensity of the battle is sharp, the writer strives for brevity and brevity even in the image, the whole weight of the hero's experiences is loaded into dialogues. The achievement of Q.Norqobil is that he emphasizes the hero's dying state and experiences. The fear of death causes a change in mood. The author focuses on three important situations before death:

1. The protagonist moves from his state to the state of another. "My eyes darkened ... I was stunned. I have no fear, no excitement. I thought it was a dream ${ }^{15 "}$.

2. After a while, the hero begins to come to his senses: "I said something to myself and recited. My closest people before my eyes - my parents, close friends, my house, our village - one left and the other began to pass. I waited for death every moment. Here they are approaching. Now my body is punctured until the bullet runs out. As I squeezed the mud in the ditch so hard, my fingers ached. I began to dip my head more and more into the mud. I never wanted to die. And in my mind, my mother, although I was not imaginary, only a small yard froze before my eyes. I raised my head to say goodbye to the world for the last time. They were only ten or fifteen steps away". ${ }^{16}$

3. The protagonist uses the last opportunity: "What came to my mind was: 'Should I be a prisoner?" I began to crawl in despair. Although the stream was shallow, I tried not to show my body. ${ }^{17}$ " Q. Norqobil puts forward an idea that has not been explicitly stated in previous works on the image of war: Because of death, man acknowledges the Creator, believes that he is under his control: A convenient opportunity is to run for only three or four minutes. I was guided by some celestial power, a divine power. It's as if my body was working with someone's mind ${ }^{18 "}$. In the story, the writer not only showed the terrible truth about the Afghan war, but also followed a unique way of expressing the hero's clash of death, the principle of impartiality.

Unlike "People of War" the philosophy of life and death is symbolic in Eshankul's works included in the book "Man led by a monkey". Because this work is not easy to digest at once, it is necessary to be well acquainted with world

\footnotetext{
${ }^{15}$ Norqobil Q. Crying behind the river. Tashkent: Sharq, 1994, 14-p.

${ }^{16}$ Norqobil Q. Crying behind the river. Tashkent: Sharq, 1994, 14-p.

${ }^{17}$ Norqobil Q. Crying behind the river. Tashkent: Sharq, 1994, 15-p.

${ }^{18}$ Norqobil Q. Crying behind the river. Tashkent: Sharq, 1994, 15-p.
} 
literature. At the same time, there is a mournful and sad tone inherent in the general spirit of the works included in this book, which allows for a deeper understanding of the inner world of mankind. About the titles X. Dostmuhammad says in the foreword to the book "The Man Leaded by a Monkey": "Let's pay attention to the names of stories and tales, from the boundless hatred of tyranny, wickedness, and depravity, are read as cries and cries arising from the anguish of the abominable, exploited, and broken destinies which give rise to such inhumane circumstances. The cries and cries that begin in one play continue in the disobedience and rebellion described in the next. ${ }^{19}$ "Yet, no matter how events change, no matter how wonderful the world is, the essence of life is based on life, love, and death. Life and love are temporary, but death is real. Therefore, the only truth of life in works of art is death and the realities associated with it are glorious and mysterious. That is why beautiful works can be created and find their readers.

In the author's story "Coffin", death has a symbolic meaning. At this point, death warns of a corrupt society, of the endless tragedy of a declining humanity. Because the city described by the writer was built in the form of a coffin. There is no place for life and everyone is doomed to death. Death has been a symbol of despair, darkness, ugliness here. We see that death is enriched with a new meaning in the work of $\mathrm{N}$. Eshonqul. The author's works are not written for the average reader, but for the intellectually gifted reader. Therefore, his works can be included in the list of "Open" works. In "Open" the writer does not follow the reader. More precisely, his work is not intended for the average reader, but for the sensitive reader. In "Open" the writer is not afraid to complicate the style, to hasten the reader. "Open" works are mastered by a reader who has experience in reading literature and feels the

\footnotetext{
${ }^{19}$ Dostmuhammad X. Nazar's promising ships (preface). Eshonqul N. The man led by the monkey. Tashkent: New Century Generation, 2004, p.
}

complexities of style. The works included in the author's book "Man led by a monkey" can easily be called "Open". Because these works require a certain aesthetic preparation from the reader. ${ }^{20} \mathrm{In}$ N. Eshonqul's work, death plays a different role. In the People of War, death is interpreted as the end of honor, the end of mental torture, while in almost all the works included in The Man Leaded by the Monkey, death is described as the basis of ugliness and darkness.

In the works of N. Eshonqul and S. Vafo, the motive of death is very common. Of course, these motifs take on a different look from the writer's point of view. In S.Vafo's interpretation, death is mainly useful in the deep study of the female psyche, while in N.Eshonqul's interpretation, it often has a symbolic meaning. There are also mystical interpretations in the works of these writers, which can be seen as attempts to understand man and the universe. In particular, the leadership of the dead as the protagonist in the stories "Dead Season" (N. Eshonqul) and "Mysterious Guest" (S. Vafo) is a reflection of the mysteries of the unseen world in everyday life, which do not meet the rational criteria we understand. Of course, these heroes play a specific role in the play. For example, while the protagonist of "Dead Season" exposes the collapsing system, the character in "Mysterious Guest" served to emphasize the different faces of members of society. It seems that not only death, but also the dead (ghosts) have a special place in the formation of socio-psychological interpretations.

Sometimes in the works of writers it is possible to observe that essentially similar realities are captured. For example, A.Yuldashev's "Farewell Party" and there is a general similarity between the stories of Qurolboy's daughter "Death is nothing". Maybe it's the result of creative intimacy. The characters in both works use death

\footnotetext{
${ }^{20}$ Rasulov A. The problem of analysis and interpretation in modern Uzbek criticism (based on the 80s and 90s of the XX century)-Written dissertation for the degree of Doctor of Philological Sciences. 129-bet
} 
as a weapon in their own interests. A similar situation is observed in world literature in the work of Somerset Maugham. Her story "Louise" is essentially close to "Farewell Party" and "Death is nothing". The common interpretations in the works of the creators of different nations are determined not only by the results of literary relations, but also by the general features of human nature. While in almost all of the works we analyze, death is presented as the end of the hero's life, in these stories both the satirical spirit of death and the selfishness of the protagonist give the impression that death remains an unchanging constant negative energy of human nature.

Writer Ulugbek Hamdam's novel "Rebellion and Obedience" became a unique work in the literature of the independence period, not only because of its formal structure, but also because of the changes in the fate of the protagonists. All of the writer's protagonists are people trying to find their identity. In the novel, the issues of faith, which are important for man, are illustrated by the example of the fate of the heroes who sought to understand the pleasures of the soul through observations about the two worlds. All three epigraphs selected for the novel serve to illuminate the essence of the work. The religious information given in the novel is based on the Christian holy book, the Bible. The illumination of Adam and Eve, and the fact that the rebellious soul finds peace in obedience, will continue in his descendants, as exemplified by the image of Akbar. In the example of the novel's protagonist Akbar, it is said that the obedience of a man who rebelled between life and death at the end of the work is a characteristic not only of Akbar, but also of mankind. The revolt in his heart will not be suppressed, either in prison or when he falls into the hands of the "great" on Russian soil. On the contrary, it hurts him day by day. The protagonist suffers from injustice at every step. Imprisonment behind a clap, his life as a flower in prison, his attempt to respond to cruelty with cruelty, his realization that this is the law of life, the changes in his psyche are examined step by step by the writer."I was applauded and imprisoned $^{21}, "$ he said. Now, even if it's not during the day, when I say no during the week, I throw it away, sometimes my opponent, sometimes my opponent, stains me with blood. But the worst thing is that I can easily raise my hand against a person. " "Is human life worthless?" This question always tortures the protagonist. In the novel, the teacher-student issue is raised to the level of art. Akbar's conversation with his teacher and the question-and-answer session are reminiscent of Aristotle and Alexander in Saddi Iskandariy. The teacher, as a person who has been healed in the hardships of life, does not take on the task of teaching his student the way of his life, but encourages him not to deviate from his way. So sometimes "why?" the questions asked will also remain open by the teacher. This is not a sign of the teacher's incompetence, but a sign that everyone must go their own way in life. The teacher always tells Akbar to go on a trip. Therefore, in one place, he reminds the student, "Everyone will have their own airfield, you find your own." The teacher's words, "Get out of here, son," were also an encouragement to travel. This journey was not just a journey, but a way for a person to find himself, to discover himself, and at the same time to enjoy the mysteries of the universe. Akbar doesn't know whether the teacher said the same to his other students or not ... But he told himself many times: "Your stomach is full of riot, rebellion ... You must go! ${ }^{22 "}$ He said. But in which way? Is it travel, a lifestyle change, or a path in a difficult observation? Akbar doesn't know that. He asked, and when he received the answer, "Take care of it yourself," he bit his tongue. As the writer puts the protagonist between life and death, he correctly demands the three most important choices a person needs to make in order to summarize himself: "travel, change of lifestyle, or the path of arduous observation".

\footnotetext{
${ }^{21}$ Hamdam U. Rebellion and obedience. Tashkent, New Age Generation. 2003, 4-b

${ }^{22}$ Hamdam U. Rebellion and obedience, p.8
} 
These are the ways of travel. The protagonist, Akbar, traverses these three paths as much as possible. It turns out that the first two ways give the expected result due to observation. The result is obedience.

Akbar is a person who tries to maintain material and spiritual balance, so he sometimes becomes a victim of injustice and sometimes finds the strength to draw a calm conclusion over a cruel life. Thus it goes through various trials. He tries to find himself in his family, in society. He can also find the strength in himself to start a new life. The protagonists of Ulugbek Hamdam's novels are people who are trying to find themselves. This also applies directly to the writer's personality. Literary scholar N.Karimov in his book "Landscapes of XX century literature" while drawing lines on Oybek's personality, said an important symbol for the writer: "Literary hero is a mirror of the writer's heart. No matter what work the reader reads, he sees the particles of the writer's heart in the image of the hero depicted in it. If the protagonist is a noble and kind person, then the writer also has such noble qualities. If the protagonist is a king and a swan, then such human qualities are not alien to the author of the work ${ }^{23}$ ". It can be seen that the heroes of U.Hamdam are serious, thoughtful people. Almost protagonists are people of transition. They often act as a kind of bridge in creating a new era in a time when the spiritual and material balance is disturbed. They are embodied in the image of a man who is ready to find his identity in the coin, and at the same time to bear the burden of the fate of the nation. Man's attempt to understand existence is not new and there is a living man who seeks to renew the world, his world, as much as possible. And that raises the issue of spirituality. Only a person with high spirituality tries to summarize himself on the border of life and death. He finds himself in the midst of life and death. A man who finds himself

\footnotetext{
${ }^{23}$ Karimov N. Landscapes of twentieth-century literature, Tashkent: Uzbekistan, 2008, 311 p.
}

lays the foundation stone for the upliftment of the nation's spirituality.

First of all, "Is it so hard for the body - the body that will sooner or later die and join the ground? If there is something behind the work something of value, something else was waiting for you. After all, the result is nothing or almost nothing! ${ }^{24 " A k b a r}$ observes that death is only a physical end. Therefore, "Is it not possible that God knowingly extends the hand of salvation to man? Is it possible that God will never tire of watching this unequal battle, even though mankind has little chance of overcoming it? " During the work, a step-by-step analysis of the changes in Akbar's psyche is convincingly based on the fact that the period from rebellion to obedience constitutes human life. The writer sheds light on the fate of the protagonists who at some point in Akbar's self-confrontation reveal his side, and proves once again that the materiality necessary for the source of life is doomed to immoral poverty. "What is the meaning of life, what is the meaning of humanity, Master? $?^{25 "}$ This question indicates that a new order is needed in Akbar's heart. The fact that the question remains unanswered is also proof that man faces every test on his own. The conversation between Akbar and his teacher is reminiscent of Saddi Iskandariy. Perhaps the writer was under the influence of the epic during the writing of the work. But Akbar's questions show the restless heart of a man seeking a solution to the rebellion. There are also episodic characters in the novel, such as Tursunboy Jontalash and Aunt Larisa, who at some point come close to Akbar. And their fate is reflected in the fate of Akbar. Thus the writer tries to solve the problem of life and death on the example of the inspection of the human spiritual world.

In the novel, Tursunboy's dying condition does not leave anyone indifferent. The fact that a person cannot be separated from the worries of the

\footnotetext{
${ }^{24}$ Karimov N. Landscapes of twentieth-century literature, Tashkent: Uzbekistan, 2008, 22 p.

${ }^{25}$ Karimov N. Landscapes of twentieth-century literature, Tashkent: Uzbekistan, 2008,26 p.
} 
world until he dies is expressed in the example of the "single brick". Tursunboy presents the work as an artistic conclusion that neither losing one's self as a result of thinking that life consists only of hard work, or becoming a helpless stranger in the end thinking that life consists only of entertainment like Aunt Larisa cannot be a measure of happiness for a person.In Hamdam's novel Sabo and Samandar, the human destiny between life and death is completely philosophical. It is clear that the purpose of death is purpose. In this case, death is not seen as a tragic end, but as a prelude to an eternal vision. In this sense, the events of the novel are reminiscent of our classic works. In the play, the question of man's attitude to love is chosen, and this love is not a desire that first burns like grass, and then satisfies the physical inclinations of self-adaptation, family, and household worries. Sabo and Samandar's destiny was not a simple love, but an expression of the desires of the heart for divine love. Therefore, the image of physical inclinations is not promoted in it. It is no coincidence that the work is not compared with Navoi's epic "Layli and Majnun". The novel depicts the love philosophy of people who have risen above their inclinations along with the worries of today's life. This philosophy permeates the hero of the life as well as his deeds. The novel is not a repetition of a famous legend in the example of the life of our contemporaries, but a human aspiration on the path of knowing God. Love for God begins with love for man. Only if a person is able to rise above physical inclinations can he know Allah. The same is true of the characters in the novel. Although Sabo and Samandar seem to live in the same line as everyone else on the surface, they are actually face to face with the souls of a lifetime. At the end of the work, they die at the same time, for the same reason. Their lifelong suffering ends in death. There is no tragedy in this end on the contrary, there is peace. This serenity is the hope of attaining the divine vision. The essence of the novel is in the epic "Layli and Majnun":

If you were me in the world,
And again the universe perished - jammed in its verses. Indeed, the vision of the novel's protagonists is hampered by worldly concerns. Because this love is an artistic interpretation of a bilingual epic free from worldly worries.

All roads lead to you,

And in you, in the verses, you will find that the aspiration of a person who has found himself, who has risen above himself, towards the Creator. The writer pays special attention to the inner world of the protagonist Samandar, in which the portals pass, because the inner world is a mirror for the appearance. In this sense, Samandar's diary attracts our attention:

"Oh love is madness! Or the world! The dream of living like people ..." "I lived without you ..."

"The world is a different world," he said

But the heart ...

That is the heart.

I want to fall in love with the world

Every morning when I wake you up

If I close my eyes to you,

In verses such as "Rebellion to God" hides the complex destiny of a man who struggles with his heart, the fate of a man who runs away from love and waits for salvation from love. At the end of the work, Shavkat Rahmon's poems "Only love ... Only love ... Another is a mirage, another is an instantaneous surah of the wind" selected as the epigraph of the novel are rediscovered.

As we watch the work of U.Hamdam, we encounter the spiritual changes taking place in the life of the protagonist. This situation begins with the story of Loneliness and continues with the example of Yusuf in Balance, and further perfected through the image of Samandar in Sabo and Samandar.

Almost all the heroes of U.Hamdam are people who are struggling to understand themselves, to know the Creator. After all, at some point in the life of the protagonist, the life of the writer is hidden:

I was a scientist!

In my nature, 
I took it to know the Seed of God.

I took the picture and

In the life of God

I came face to face with myself. ${ }^{26}$

The lines from U.Hamdam's "Biography" show that the transformation of the psyche takes place first of all in the life of the writer. Almost every paragraph of the "Biography" contains the fate of the author's heroes:

There was also a lover -

Madness,

There was poetry on his lips, a fire in his bosom.

He is still my slice

Destroys,

He is still a lone wolf - if Samandar's fate is hidden in his verses,

Another man living in my heart,

Let's build a new world.

To his neighbor Majnun

No his consciousness,

Dilkash is the name of the builder Farhod in his poems the image of Yusuf appears. Because of this, the writer exclaims in one place: U. Hamdam's works are diverse in genre, but there is a monotony in this diversity. It's an effort to find your identity. These paths are summarized between life and death. That is why his heroes look death in the face and seek refuge in him.

In the prose of independence, knowing God, analyzing one's own psyche, in a word, having the image of an analytical hero, U. Hamdam seems to swell in his work. This was the case in the early twentieth century in the novel Night and Day with the example of Miryokub. Later it was continued in the novels "Ulugbek's Treasure" and "Old World" and was vividly expressed in the works of U. Hamdam. The fact that a literary hero tries to examine not only his life, but also the talotums in his psyche, and understands others, signifies his righteousness in the way of self-realization. The path of the

\footnotetext{
${ }^{26}$ Hamdam U. Translation hol. Dilnura in the distance,

Tashkent: Akademnashr, 2010, 176-p.
}

righteous is the path of spirituality and enlightenment in a climate of spirituality.

In this respect, the image of Samandar created by U.Hamdam is embodied in the image of a hero who is acquainted with the mysteries of divine enlightenment, who mediates his figurative love to divine love. It is therefore no coincidence that the deaths of Samandar and Sabo occur at the same time. So their death is far from tragic. This death connects them to the goal.

The interpretation of the problem of death and life in relation to personal inclinations is also observed in the work of Zulfiya Qurolboy's daughter. Most of the heroes created by Adiba are simple, immersed in their own worries who are still small and insignificant under the burden that is too heavy for a single destiny. Among the characters he created, there are also characters who are more humble in character and indecisive than those who fight for honor. Creators created by the daughter of Z.Qurolboy's daughter allow the reader to walk in the streets of the heart, to inspect ourselves. At the same time, there are new interpretations in the works of Z.Qurolboy's daughter, which are essentially sealed for eternity. One of such heroes is Nazar Chol from the story "Oh, life". In Uzbek literature there are several images of enlightened old men. Unlike them, Nazar the old man looks at life selfishly and is judged according to his intentions."I'm not going to die, you know, I'm not going to die! $!^{27 "}$ The old man shouted in a rage. - I live, I live for many years! I will live a hundred years after you, a hundred years! One hundred years! " Adiba means through the fate of old Nazar that the denial of death is a great tragedy. As we read the story, we realize that it is bliss to be able to die in time, and that death is also a blessing to man. To feel that death is a blessing for a person, it is enough to remember the "Legend of Eternity" from E.Vakhidov's epic "Rebellion of Spirits". An absurd analysis of the problem of life and death,

\footnotetext{
${ }^{27}$ Kurolboy's daughter Z. Oh, life! Angel of evil, Tashkent: Yangi asr avlodi, 232-p.
} 
such as the insane pursuit of meaningless life, the denial of death, in a word, the rebellion against the creator Kurolboy's daughter raised her creativity to a special level. Unlike Nazar Chol, in Hilola, the protagonist faces death every minute. Even in such a situation, trying not to be deprived of the happiness that is meant for him dispels any fear. In the philosophy of existentialism, there is the concept of a borderline situation. It gives man the right to choose on the border of life and death. It is within this boundary that the essence of man is revealed. Look, for Hilola, the short moments that add meaning to her life were preferable to the constant continuity. So he chose to live a short and meaningful life rather than a boring life that the end was not even known to him. The bitter taste of loneliness is no stranger to Hilala. Even Hilala's friend, who has white hair, is happy with her: "She looked really ugly. Unlike Hilala's wandering, aching face, her gaze was calm and quiet. The feeling of satisfaction with his destiny and life was clearly reflected in his face. I have not seen such an expression in Hilala's eyes for years," said the storyteller. Loneliness is not typical of a slave. Happiness for a woman is the pleasure found in the family, living with a worthy couple. The other is mirage. Happiness is as measured as human life. The first measure of happiness begins in the family. The family manages the spiritual balance. Tragedy begins where this balance is disturbed. The story is also valuable in terms of conveying this meaning to us.

Uncle Khaliq is a vivid expression of the relationship between the individual and the crowd. The death of a person whose lifelong identity is not valued by anyone also ends in tragedy. Uncle Khaliq is a man who never had self-respect. Although constant cowardice is the cause of helplessness, the writer reveals the tragedy of the crowd and the individual by emphasizing the relationship between people and Uncle Khaliq, not the weakness of Uncle Khaliq. Burying a living person is not only a sign of humiliation, but also of atheism. In the story, death served as a tool of revelation in showing people's interactions. Adiba skillfully uses irony in expression. People around Uncle Khaliq want his death equally. They are tired not only of the living uncle, but also of his death. Benefit bypasses human dignity. Due to death, the veiled mask is removed and the original face is seen. "Bury it," said the doctors. That's what happens to some people, 'said Nortohta, looking at everyone one by one sharply. "She's dead." He is already dead ..."The end of the story is even more tragic: "Nortokhta's relatives agreed with each other: 'He died the day before, and the next day he will die anyway ${ }^{28}$.' The subject of crowds has been frequently addressed in fiction before. In Adiba's work, too, the crowd is highlighted as a separate problem, which is not in vain. Because solving the problem of the crowd is a pressing issue before humanity. After all, the existence of a nation is determined not by the crowd, but by the presence of individuals. Tragic spirit prevails in the works of Z.Qurolboy's daughter. But there is an important aspect that connects them. It is the struggle of people who are doomed to be forgotten by society to prove their existence.

Zulfiya Qurolboy's daughter story "Woman" took the writer's work to another level. This story is valuable for its sudden insight into a person's pre-death situation and its vitality. In it, real reality flows into art and arouses aesthetic pleasure in the reader. Adiba reflects in the image of the psyche of the sick protagonist that a person is thirsty for life in any situation:

"She opened her eyes. The light was now reflected in his pupils.

"How lovely ... Another morning of life has dawned," she closed her eyes, sucked in the sunlight, and then whispered softly, "How much I love you, sunshine! ${ }^{29 "}$ The sun shone brightly. The woman was completely immersed in the sun ..." Adiba convincingly illuminates the protagonist's thirst for life, living the last days of

\footnotetext{
${ }^{28}$ Kurolboy qizi Z. Khaliq uncle. Angel of evil, Tashkent: Yangi asr avlodi, 232-p.

${ }^{29}$ Qurolboy's daugter Z. Woman. Death is nothing. Tashkent: Yangi asr avlodi, 2011. - 297-p.
} 
his life. The reality of life is fully embodied before our eyes. Not only that but also Nazokat's courageous behavior in the face of death is astonishing. The patient, whose stomach is becoming more and more swollen, does not want to show himself to his relatives in this way. She does not want this scene to remain frozen in front of her husband and children for a lifetime. ${ }^{30} \mathrm{He}$ doesn't even want the doctor to completely remove the water from his stomach, to find death in an ugly alpha. The desire for beauty of a woman who is living the last minutes of her life means that the quality of beauty is eternal because of a woman.

"Doctor ..." Nazokat put the gold ring on her finger in the doctor's pocket. "Take some water, please." Just to the end!

The doctor did not answer again. He didn't even look. He did not look at her face even after the woman's hand went into his pocket. But...

"Nurse!" He called, looking down the hall.

Nazokat smiles, then he took the powder from under his pillow ... ${ }^{31}$ "

There are enough characters in our literature who bravely feed on death. One such work is Abdullah Qahhor's "A Thousand and One Souls."Mastura Aliyeva in the story comes back to life first of all according to her destiny, as well as her strong will and the writer's purpose. In life, such patients often cannot survive. But the desire to live overcomes death. In Abdullah Qahhor's work, especially the inner enlightenment of the hearts of female characters is not so noticeable. Nevertheless, according to the writer's peculiar style, one or two strokes alone were enough to express the fact that Mastura had a strong will. The will in Mastura Aliyeva can be said to have literally shifted from the personality of the writer. After all, it was up to the writer to get a death knell. In the book "In memory of Abdulla Qahhor's contemporaries" K. Simonov's important confession about Abdulla Qahhor's personality

\footnotetext{
${ }^{30}$ Qurolboy's daughter Z. Kholiq uncle, 87-p.

${ }^{31}$ Qurolboy's daughter Z. Woman. 305-p.
}

attracts our attention. "I saw him in hospital just the day before he died. He did not want to die, even though he knew that death was dusting him off, and by his very nature he was resilient even in the face of death. He was leaning on a pillow on the bed, breathing heavily, and his radiant face, which did not know fear, was a little embarrassed that he could not run to the future of his friends. I was amazed to see it ${ }^{32} "$. They also remember Abdullah Qahhor once suffering from diabetes for more than twenty years and once complaining to no one. Shuhrat, who was with Abdullah Qahhor in the last minutes of his life, recalls:"He lived his life to the last breath with the same courage as he lived and created," he said. I remember his death: "Saying goodbye to life is an art. I think it takes perseverance and determination ${ }^{33}$ ". U.Normatov in his book "Edification of teacher" gave the following memories of Shuhrat, which illuminate his personality: "I lived the age of a prophet. It is impossible for the Prophet Muhammad (peace and blessings of Allaah be upon him) to knock on the door so that his beloved Ummah would not go beyond my age."I confess my fate ... I beg you to stay with me from the moment I die until I enter the grave ${ }^{34}$ ". When you take my coffin to Tashkent, you will, of course, put it in a box and put it on display. Before them, wash and wrap in a shroud. Don't shave my head, shave my beard yourself ..." Courage to face death, to accept destiny, requires strong spiritual preparation. But such power cannot be expected from everyone. In this sense, some aspects of the writer's personality have been transferred to his protagonists. The story of "A Thousand and One Souls" is a clear proof of this. If Abdullah Qahhor tends to embody the psyche of female characters with one or two strokes, then Z. The gunman's daughter penetrates deeper into the female psyche. And she doesn't forget the femininity of her character every minute.

\footnotetext{
32 In memory of Abdullah Qahhor's contemporaries, Tashkent: Literature and Art Publishing House, 1987, p. 50.

${ }^{33}$ Normatov U. Edification of Teacher, Tashkent: National Library of Uzbekistan, 2007, p. 79.

${ }^{34}$ In Memory of Abdullah Qahhor's Contemporaries, 334 p.
} 
The common similarity between the stories of both writers is that they cover the pre-death situations of female protagonists. As Adiba depicts the death of the protagonist, he re-focuses on the sun's rays. "Suddenly the sun was dazzlingly white, illuminating the vast sky, and then it seemed to slow down, and when it reached the top of the hospital, it lowered all the light into the open room, and at that moment the handsome and beautiful woman on the bed smiled, trying to redden her eyelids. He wanted to be reflected in his beloved pupils, but he could not find them, he could only see them in the diamond eyes of the ring that appeared on the woman's fingers ${ }^{35}$. The success of the story is not in the fact that it informs the protagonist of his pre-death condition or death, but in what aesthetic task death imposes on the protagonist and how the reader can enjoy it.

There are also interpretations in Uzbek literature that death eliminates social inequality. Through the fate of Lolakhan's character in Lukman Borikhan's novel People in the Heat, the writer raises the idea that the suffocation of natural desires leads to tragedy. Blind obedience to tradition deprives one of freedom. Tragedy begins where freedom is stifled. By narrating a small event in a novel, a big social problem is raised. All events are conducted from the point of view of the hero Samad, analyzed, and the will to judge is given to the reader.

Despite the fact that the mountain people, who went to the desert in search of a happy life, were immersed in worries of a worse life than in the mountains, as a result, "we are getting saltier, the desert is resisting dreams and hopes are expressed in the predominance of irony-pitching. The whole essence of the work is that naturalness cannot be suffocated. The current idea is reflected in the tragic consequences of the misappropriation of the desert, especially in the case of Lolakhan, who became a treasure in the heart of the desert.

Lolakhan is a widow, a twenty-three-yearold aunt, an honorary deputy due to her

\footnotetext{
${ }^{35}$ Qurolboy Qizi Z. Woman, 305-p.
}

widowhood. In Lolaxon's depictions of turning into a living puppet, the writer exposes a society in crisis. But Lolahon is a "sane bride" who feels she is resisting her wishes. The former honorary MP is genuinely horrified when he is confronted by an old woman, as if he sees his future. The respect shown to Lolakhan cannot promise him a happy future. "Out of love, half out of life", Lolakhan could not call "eternal separation, eternal vision". Because, in the words of the poet, she needed feminine happiness, not the throne of angels. Therefore, when Ulash hears the agronomist's poem addressed to him, he "trembles involuntarily like an animal with a mark on its forehead." Lolahon is skeptical of the fame that is being forced upon him. At least he wants to share the sweet taste of the phrase "the whole world is on his lips" with teenager Samad. Usually, rebellion occurs where desires are stifled. Through the fate of Lolakhan, who was a victim of a lifelong inability to bear the burden of widowhood and a volcanic eruption of his secret greed, the writer was able to convey that nature cannot be resisted, that man is a part of nature, that separating man from his nature can lead to inevitable tragedy. The author convincingly illuminates his senseless life and its tragic ending through the image of Lolakhon. Lukman Borikhan skillfully uses satire to contrast the crowd's reaction to Lolakhan's experiences:

"Your cousin Lolakhan also took a picture of my sister." Sister Lolakhon leaned her head against the statue and took a picture crying. Your relative praised you. It looks great on the cover of a magazine, "he said.

"Did Lolakhon cry with the cup?" I asked and my heart pounding.

"Yes, she cried like the girls her friends took her out of the game."

In fact, Lolakhon is completely forgotten. His condemnation of walking with a sad face, as if to show his respect by the people with a sad sigh in front of Lolakhan, is taken with a bitter laugh. In short, Lolakhon's brother-in-law Ashur puts an end to such a ridiculous life. Although Lolakhon's 
death shocks the reader, it draws a little reassurance from the end of a meaningless life.

One of the most important aspects of the novel is that in Uzbek literature there is almost no work in this spirit, in which the subtle nuances of the female psyche are rhythmically conveyed through the language of the protagonist child. Although the work, which is dominated by the spirit of satire, is not new to readers (this can be seen in the example of Aziz Nesin in Turkish literature, M. Bulgakov in Russian literature), especially the natural development of the plates, in which the role of the character shows the skill of the writer in creating the image.

This novel by Lukman Burikhan became a new breath in Uzbek novels. The ability to illuminate their vast spiritual worlds through such small masters of destiny as Lolakhan, Ergash, Samad, and the creation of images that rose to the level of a person among the masses made it possible to truly breathe freely in fiction. It can be said that the interpretation of an image, especially that of Lolakhan, showed that Uzbek literature was rising to a special stage in the question of the psyche of the individual.

From the above considerations, it can be said that the prose of the independence period emphasized the natural-biological and nationalIslamic interpretations of the issue, as well as the socio-psychological aspects, in explaining to the reader the essence of the problem of life and death. This made it possible to explore the inner world of the character. Such an analysis was a bold step in trying to define the essence. It was also realized that the socialization of an individual and his alienation from his own nature could lead him to various tragedies. At the same time, death also served the function of spiritual purification, which can be presented as a way of salvation for a person who is losing his self. In the considered works of Uzbek prose, death is presented as a way to the goal. Sometimes life is expressed through symbols. The symbols provided a bubble of expression. Sometimes death emerges as a carrier of the idea. The writer means by death that any idea is doomed to collapse. Hence, death is interpreted not only as a natural end, but also as the end of the product of contemplation.

At the same time, on the border of life and death, the original image of man is revealed. This boundary is determined in tragic situations, not in a permanent state. In the writers 'interpretation, such a tragedy can occur when social factors take precedence over natural feelings, when the balance is disturbed. Sometimes the role of the environment is also emphasized in situations that lead to the death of the character. The artistic observation that the place that connects life and death is the path of love has risen to a new level in the prose of the independence period. The continuation of the traditions of our classical literature in the prose of independence is not a copy of ancient motifs, but a modern artistic interpretation of the pursuit of self-realization.

\section{References:}

[1] Eshonqul N. An unopened door. You can't catch the wind. Tashkent: National Library of Uzbekistan, 2005.

[2] Eshonqul N. You can't catch the wind. Tashkent: National Library of Uzbekistan, 2005.

[3] Eshonqul N. People of war. You can't catch the wind. - Tashkent: National Library of Uzbekistan, 2005.

[4] Chulpon. What is literature? - Tashkent: Cholpon. 1993.

[5] Yuldashev Q. Burning word. - Tashkent: Yangi asr avlodi, 2006.

[6] Masahiko Sh. A mummy's diary (translated from English by A. Obidov).ziyouz.com

[7] A.Yuldashev. A trace in the heart. Goodbye beauty. - Tashkent: Uzbekistan, 2011.

[8] Ghazali Abu Hamid. A book of remembrance of death. Tashkent: Movarounnahr, 2004.

[9] Moudi R. Life after death. -Tashkent: Mehnat, 1992. 
[10] Norqobil Q. Crying behind the river. Tashkent: Sharq, 1994.

[11] Dostmuhammad X. Nazar's promising ships (preface). Eshonqul N. The man led by the monkey. Tashkent: New Century Generation, 2004.

[12] Rasulov A. The problem of analysis and interpretation in modern Uzbek criticism (based on the 80s and 90s of the XX century). The dissertation for the degree of Doctor of Philological Sciences ... Tashkent: 2002.

[13] Hamdam U. Rebellion and obedience. Tashkent, New Age Generation. 2003.

[14] Karimov N. Landscapes of twentiethcentury literature. - Tashkent: Uzbekistan, 2008.

[15] Hamdam U. Translation hol. Dilnura in the distance. Tashkent: Akademnashr, 2010.

[16] Qurolboy's daughter Z. Oh, life! Angel of evil. Tashkent: Yangi asr avlodi, 2011.

[17] Kurolboy's daughter Z. Holy uncle. Angel of evil. Tashkent: Yangi asr avlodi, 2011

[18] Qurolboy's daughter Z. Woman. Death is nothing. - Tashkent: Yangi asr avlodi, 2011.

[19] In memory of Abdullah Qahhor's contemporaries. - Tashkent: Literature and Art Publishing House, 1987.

[20] Normatov U. Teacher's example. Tashkent: National Library of Uzbekistan, 2007. 